\title{
Formin-Binding Protein 1
}

National Cancer Institute

\section{Source}

National Cancer Institute. Formin-Binding Protein 1. NCI Thesaurus. Code C97542.

Formin-binding protein 1 (617 aa, 71 kDa) is encoded by the human FNBP1 gene. This protein plays a role in cytoskeletal remodeling during endocytosis. 